\title{
High species richness and unique composition of the tanaidacean communities associated with five areas in the Pacific polymetallic nodule fields
}

\author{
Błażewicz Magdalena ${ }^{1}$, Jóźwiak Piotr ${ }^{1}$, Menot Lenaick ${ }^{2}$, Pabis Krzysztof 1, *
}

${ }^{1}$ Laboratory of Polar Biology and Oceanobiology, University of Łódź, Banacha 12/16, 90-237 Łódź,

Poland

${ }^{2}$ Laboratoire Environnement Profond, Centre Bretagne - ZI de la Pointe du Diable - CS 10070 - 29280

Plouzané, France

* Corresponding author : Krzysztof Pabis, email address : cataclysta@wp.pl

\begin{abstract}
:
The benthic fauna associated with polymetallic nodule fields is scarcely studied. Studies on species richness and distribution patterns are indispensable for the conservation of the abyssal ecosystem and for the development of management strategies for sustained commercial activities in the future. Here, we analysed the distribution patterns and diversity of tanaidacean communities associated with four International Seabed Authority licenced areas (BGR, IOM, GSR, Ifremer) located in the Clarion-Clipperton Fracture Zone (NorthEast equatorial Pacific) and the one Area of Particular Environmental Interests (APEI3). The study was based on 34 box core samples collected at depths ranging from 4,200 to 5,000 m. Altogether, 98 species (446 individuals) were recorded, of which 47 were singletons. Most tanaidaceans (78 species) were unique to a specific area. The highest densities, species richness and diversity were recorded in the BGR license area, while the lowest values were found in the APEI3. Our results correspond to the differences in productivity observed among the five areas. Species accumulation curves demonstrated substantial undersampling, and the final conclusions about tanaidaceans diversity in the CCFZ should be treated with caution, requiring further studies with higher sampling effort. The extremely low densities $(2.3 \pm 2.3$ ind./0.25 m2) and species richness (five species) recorded in the APEI3 suggest a need for the revision of planned conservations strategies in the CCFZ, although it was the most scarcely sampled area and our results are therefore not representative of the entire site.
\end{abstract}

\section{Highlights}

- First large scale quantitative assessment of tanaidacean communities associated with polymetallic nodule fields. Unique species composition associated with different licence areas of the Clarion Clipperton Fracture Zone. Very low diversity and abundance of tanaidaceans in the Area of Particular Environmental Interests (APEI3)

Keywords : Peracarida, biodiversity, productivity, deep-sea mining, conservation 


\section{Introduction}

The deep-sea polymetallic nodule fields located in the north-eastern equatorial Pacific, known as the Clarion-Clipperton Fracture Zone (CCFZ), constitute a large and unique habitat for benthic fauna. Variations in organic matter input, a complex hydrography or the presence of physical barriers as the chains of sea mountains and fractures in a vast area of $6,000,000$ $\mathrm{km}^{2}$, at depths of 4,000-5,500 m (Khripounoff et al. 2006, Mewes et al. 2014, Juan et al. 2018) make the CCFZ a distinctive large-scale natural laboratory ideal for analysing the influences of habitat heterogeneity, surface-productivity or sediment structure on the distribution of various taxonomic and ecological groups (e.g. Miljutin et al. 2011, Jones et al. 2017). Recent studies have also demonstrated that ecosystems of polymetallic nodules host unique and largely unknown benthic communities (Vanreusel et al. 2016).

The CCFZ is a vast commercially important area for the extraction of polymetallic nodules, regulated by the International Seabed Authority (ISA) (Hein et al. 2013). Nodule fields are a source of copper, nickel and cobalt; however, economic interests clash with the need for conservation planning in the deep sea (Levin et al. 2016, Dunn et al. 2018, Taboada et al. 2018).

Recent studies have demonstrated that planned mining activities have serious negative environmental impacts, and the post-disturbance recovery of the impacted ecosystem will be an extremely long process, measured in the scale of decades or even thousands of years (Jones et al, 2016, Kaiser et al. 2017 and references therein). According to previous studies, nodule extraction directly impacts large sessile organisms as well as smaller infaunal species (Jumars 1981, Miljutin et al. 2011, Jones et al. 2017, Vanreusel et al. 2016), while resuspended sediment will likely have a negative effect on the filtrating fauna and on numerous smaller benthic organisms (Jumars 1981, Glover and Smith 2003).

Against this background, a baseline assessment of diversity and distribution patterns is essential for predictions and for the development of reliable response scenarios of disturbed ecosystems. The relatively low sampling coverage in a vast and fully unrecognised ecosystem makes final conclusions on diversity, species rarity and/or dispersal abilities highly uncertain, but nevertheless, the findings of previous studies point to a substantial delay in polymetallic nodule mining until the long-term ecological impacts can be adequately assessed (Kim 2017). The outlined issues are important in the context of a "blue economy" and constitute an important element of the taxon-focused approach for developing conservation strategies for deep-sea ecosystems (Costello and Chaudhary 2017, Glover et al. 2018). At the same time, our knowledge on the diversity and composition of fauna associated with polymetallic 
nodules in the CCFZ is still insufficient, with few ecological studies mainly published in the last 4 years (e.g. Renaud-Mernant and Gourbault 1990, Janssen et al. 2015, Singh et al. 2016, Amon et al. 2017, Kersten et al. 2017, Wilson 2017). There are also only few taxonomic descriptions or species registers (e.g. Dahlgren et al. 2016, Herzog et al. 2018, Kersken et al. 2018, Bonifacio and Menot 2018).

Recent studies have shown that small peracarid crustaceans, such as Tanaidacea, are an important element of bathyal and abyssal communities and belong to the most highly underestimated deep-sea organisms, characterised by a high number of singletons and a high number of species new to science (Błażewicz-Paszkowycz et al. 2012, BłażewiczPaszkowycz et al. 2015, Pabis et al. 2015). Their small size, tubiculous life form, extremely low mobility and lack of a planktonic larval stage make them an ideal taxon for diversity studies and the analysis of multiscale (e.g. microhabitat level, regional diversity) distribution patterns (Błażewicz-Paszkowycz et al. 2012, Zeppilli et al. 2016). For the same reasons, they might be used as important indicators of potential changes in the deep-sea environment. The naturally low population size and their restricted dispersal abilities make them particularly sensitive to disturbance and habitat fragmentation (Błażewicz-Paszkowycz et al. 2012, Hilario et al. 2015), and their responses to disturbances may differ substantially from the patterns observed for other invertebrates. Based on the above, we even expect that many species of tanaidaceans associated with nodule fields will go extinct during mining activities before they can be described (Van Dover et al. 2017). In this context, there is an urgent need to confront earlier studies with the results based on the analysis of those smallest representatives of the deep-sea macrofauna, which have been scarcely studied so far (Smet et al 2017, Wilson 2017, Ok Hwan et al. 2018). Therefore, our study provides a first large-scale quantitative assessment of the tanaidacean communities associated with polymetallic nodule fields in the Clarion-Clipperton Fracture Zone. We hypothesise that the low dispersal potential of tanaidaceans will result in substantial differences in species composition between the studied areas, while less productive Area of Particular Environmental Interests 3 (APEI3) will be characterized by lower abundance and species richness.

\section{Material and methods}

\subsection{Sampling and environmental factors}

The material was collected in four areas of the Equatorial North-East Pacific, licensed by the International Seabed Authority (ISA); all areas were located in the Clarion-Clipperton Fracture Zone $\left(6^{\circ} \mathrm{N}\right.$ and $20^{\circ} \mathrm{N}, 120^{\circ} \mathrm{W}$ and $\left.160^{\circ} \mathrm{W}\right)$ and in the one Area of Particular 
Environmental Interest (APEI3) precluded from potential mining. The area of the Pacific manganase nodule belt stretches for about 5,000 km (Mewes et al. 2014). Altogether, 34 box cores (sampling area of $0.25 \mathrm{~m}^{2}$ ) were collected in March and April of 2015 during the expedition on board of the RV Sonne (SO 239) at depths ranging from 4,200 to 5,000 m (Kaiser et al. 2015); each core was sliced into three layers $(0-3,3-5$ and 5-10 cm). Subsequently, each layer was sieved on board through a 300- $\mu$ m mesh, and the obtained fauna was preserved in cold $96 \%$ ethanol. The sieve residues of the two deeper layers were fixed in $4 \%$ formaldehyde solution for 2 to 4 days and later transferred into $80 \%$ ethanol. Nine samples were collected in the German license area (BGR - German Federal Institute for Geosciences and Natural Resources), nine in the IOM - Interoceanmetal Joint Organization (Bulgaria, Cuba, Czech Republic, Poland, Russian Federation, Slovakia), five in the Belgian area (GSR - Global Sea Mineral Resources), six in the French license area (Ifremer) and five in APEI3 (Table 1). Samples 51 (BGR), 105 (IOM), 203 and 209 (APEI3) could not be treated as fully quantitative due to disturbances in the sampling procedure. The distribution of the stations in the five remotely situated areas of the CCFZ allowed for comparisons of species richness and fauna composition. The environmental factors (Table 2) analysed at each of the sites were grain size fractions, total nitrogen (TN), total organic carbon (TOC), total organic matter (TOM), chloroplastic pigment equivalents (CPE) and chlorophyll a content. The material was collected using a multi-corer (MUC). The analytical procedures are described in detail in Hauquier et al. (2018) and Volz et al. (2018). Generally, the sediments and the environmental factors were similar in all license areas; only the area APEI3 was characterised by a higher amount of clay fractions and lower TOC and TOM levels (Hauquier et al. 2018, Volz et al. 2018).

\subsection{Data analysis}

The tanaidacean fauna was identified to morphospecies. Median values of abundance, species richness ( $\mathrm{S}$ - number of species per sample) and diversity (Shannon Index) with quartiles were calculated for each studied area (Magurran 2004). As the data were not normally distributed, the statistical significance of differences in diversity, species richness and abundance among sites was tested via the Kruskal-Wallis test. Post-hoc testing was performed using Dunn's test in the Statistica 6 package. Chao 1 and Chao 2, as well as Jackknife 1 and Jackknife 2 estimators of species richness, were also used (Canning-Clode et al. 2008), applying Primer 7. Sample 196 from APEI3 was excluded from the species richness and diversity analysis due to the presence of only one damaged, unidentified individual. 
Hierarchical agglomerative clustering analysis based on the Bray-Curtis formula was used by applying the group average method. Data were not transformed due to the extremely low abundance of tanaidaceans. A SIMPROF test with 5\% significance level was performed to assess the multivariate structure within groups (Clarke and Gorley 2015). The numbers of singletons and species recorded in one sample only were calculated for the entire material and for each area separately. We also determined the number of species unique to each of the areas.

\section{Results}

Altogether, 98 tanaidacean species (446 individuals) were found. Species number and community composition differed significantly among the five studied areas. We recorded 42 species in BGR, 31 species in IOM, 22 species in GSR, 20 in Ifremer and five species in the APEI3 area. Both Jackknife and Chao estimators indicated substantial undersampling (Fig. 1), demonstrating that more species can be found in the studied region.

Many species were unique to only one area (Table 3). The highest proportion of the unique species (19 species, 95\%) was found in the Ifremer area, while the lowest was recorded in IOM area (15 species, 48\%). Moreover, 78 species were found in one area only, while only two species were recorded in three areas (Fig 2). We also recorded a high number of singletons (47 species) and species restricted to only one sample (58 species). In each of the studied areas, the number of singletons was also high, varying from $38 \%$ in the BGR area to $100 \%$ in the APEI3 area (Table 3). The number of species found only in one sample from a given area varied from $54 \%$ in IOM to $100 \%$ in APEI3 (Table 3); only three species had a total abundance higher than 10 individuals, while only nine species were found in more than three samples.

Generally, the number of species common to different areas was low (Table 4); the highest numbers of such species were found between the BGR and IOM (14 species) and between the BGR and the GSR area (five species).

The highest mean densities were found in the BGR area $(24.4 \pm 13.6$ ind./0.25 m²), while the lowest were found in APEI3, with only $2.3 \pm 2.3$ ind./0.25 $\mathrm{m}^{2}$. Median values with quartiles for those two areas was 21.0 ind./0.25 $\mathrm{m}^{2}$ (Lower quartile 17.0, Upper quartile 31.0) and 2.3 ind./0.25 $\mathrm{m}^{2}$ (Lower quartile 1.0, Upper quartile 2.0) respectively (Fig. 3). The mean number of species per sample varied from $8.1 \pm 3.2 \mathrm{spec} . / 0.25 \mathrm{~m}^{2}$ in the BGR area to $1.2 \pm$ 0.5 spec./0.25 $\mathrm{m}^{2}$ in APEI3. Median values with quartiles for those two areas was 9.0 spec./0.25 $\mathrm{m}^{2}$ (Lower quartile 6.0, Upper quartile 11.0) and $1.0 \mathrm{spec} . / 0.25 \mathrm{~m}^{2}$ (Lower quartile 
1.0, Upper quartile 1.5) respectively. The highest values of the Shannon Index were recorded in the BGR area with $1.7 \pm 0.4$, while the lowest were found in the APEI3 with $0.1 \pm 0.3$. Median value with quartiles for the BGR was 1.9 (Lower quartile 1.6, Upper quartile 2.1). Significant differences in species richness, abundance and diversity were found only between the BGR area and APEI3 (Kruskal-Wallis test, Dunn's test $\mathrm{p}<0.05$ ).

Cluster analysis yielded three large sample groups, albeit at a low level of similarity (5-10\%) (Fig. 4). Three samples from APEI 3 (203, 195, 209) did not group with any other sample. Samples from the GSR and Ifremer areas as well as samples from BGR and IOM were grouped together.

\section{Discussion}

Given the large area of the CCFZ, the total sampling area was extremely small and covered only $8.75 \mathrm{~m}^{2}$ of the sea floor. Despite substantial undersampling of the studied area, 98 species were recorded in only 34 samples gathered with a quantitative sampler that collects fauna from a small sampling point. Diversity was relatively high, even when compared to that of important benthic macroinvertebrates such as polychaetes or nematodes (Glover et al. 2002, Singh et al. 2016). A previous study on the polychaete fauna from the CCFZ yielded 183 species from an area of $21 \mathrm{~m}^{2}$ (Glover et al. 2002). The species richness of the tanaidacean fauna associated with the CCFZ is also relative high when compared to other deep-sea tanaidacean studies with similar sampling efforts (Błażewicz-Paszkowycz et al. 2015, Pabis et al. 2015). Even in studies in the abyssal of the Kurile Kamchatka Trench area, 77 species were recorded in 20 samples collected from a considerably larger surface area with the use of an epibenthic sled (EBS), sampling fauna across a large distance and from various microhabitats (Golovan et al. 2017). The high species richness recorded in the CCFZ might be due to the large scale of the sampled area (about $1,400 \mathrm{~km}$ ) as well as the high heterogeneity of the environment, mainly caused by the complex topography, the presence of natural barriers and differences in productivity among the license areas (Janssen et al. 2015, Zeppilli et al. 2016, Volz et al. 2018). In a similar study, Wilson (2017) found a high number of tanaidacean species at two sites located in the CCFZ in material collected within the project Deep Ocean Mining Environmental Study (DOMES). He recorded 46 species in $150.25 \mathrm{~m}^{2}$ box core samples collected in the DOMES site $\mathrm{C}$ and 61 species in 52 box core samples collected at DOMES site A.

Studies on nematode communities have also demonstrated the substantial microhabitat heterogeneity in the CCFZ (Singh et al. 2016). In our study, high levels of TOM resulted in a 
higher abundance and species number per sample, although the largest differences in food availability and sediment structure were recorded only between APEI3, while all other areas were relatively homogenous in terms of the analysed abiotic factors. These results are not surprising, since productivity is among the key factors structuring deep-sea benthic communities (Glover et al. 2002, Wei et al. 2010). Meiofaunal abundance in APEI3 was also significantly lower than in other parts of the CCFZ (Hauquier et al. 2018). Differences in tanaidacean abundance between areas characterised by different productivity levels have also been recorded in the Korean Exploration Claim Area of the CCFZ (Ok Hwan et al. 2018).

The extremely low similarity in the faunistic composition among sites and the high number of singletons are striking; however, the sampling effort in each study area was low. The highest number of common species was found in two neighbouring areas (IOM and BGR), although it was still relatively low (14 species) taking into account that those areas had the highest species richness among all sites. The results of the cluster analysis did not demonstrate a distinct pattern, although this fact is associated with the number of singletons and the generally low abundance of the majority of the recorded species. Low tanaidacean abundance, high number of singletons and substantial undersampling have also been recorded in the CCFZ by Wilson in the DOMES site A and C.

Janssen et al. (2015) have demonstrated that the distribution of many isopods is restricted to only one area, although only Ifremer and BGR were studied. Those peracarids are similar to tanaidaceans as they lack a planktonic larval state and have limited dispersal abilities (Brandt et al. 2007). Nevertheless, a unique species composition was also noted for polychaetes, while on the contrary, some isopod species had wide distributions (Janssen et al. (2015). Molecular studies of selected tanaidaceans from Ifremer and BGR areas have confirmed unique community structures, although one species was common to both areas (Jakiel et al. in press). A similar result, based on material collected within the project DOMES, has been reported by Wilson (2017).

We only have limited information about the biology of tanaidaceans, although they are generally believed to have similar development modes, feeding strategies and mobility types (Błażewicz et al. 2012). Those knowledge gaps strongly impede the analysis of mechanisms promoting the dispersal of particular species. Moreover, our knowledge about species richness of the abyssal tanaidacean fauna is extremely scarce, and recent studies have shown that the estimations of diversity and distribution patterns probably suffer from a strong sampling bias, associated with low sampling efforts (Jóźwiak et al., this volume). The low number of samples precludes a detailed analysis of distribution patterns, especially at the microhabitat 
level, as well as a meaningful multiscale analysis. Taking into account the substantial undersampling and the number of collected singletons, as well as the complexity of environmental factors occurring at different parts of the CCFZ, our final conclusion about the level of rarity and the distribution of species should be taken with a pinch of salt.

Nevertheless, our results indicate substantial challenges associated with future conservation planning in the CCFZ. The appropriate recognition of endemism is crucial for conservation strategies, and areas with a high number of endemic species should gain priority conservation status (Costello and Chaudhury 2017). However, we still lack sufficient data about the distribution patterns of the majority of macroinvertebrates in the CCFZ, including its smallest representants such as the tanaidaceans. A high level of rarity and/or patchiness, such as in the case of the CCFZ tanaidacean fauna, poses important questions about the vulnerability of their communities to disturbances associated with mining activities. Low densities and a low connectivity between small populations might prolong regeneration following disturbance. Moreover, we can suspect that at least some of those species are not only rare, but have also relatively small spatial ranges $(78$ species were recorded in one area only), and such rare and narrow-ranged species are most vulnerable to extinction (Hilario et al. 2015, Costello and Chaudhary 2017). Previous studies have shown that the recovery of CCFZ benthic communities following simulated mining activities was slow, albeit with considerable differences among the various taxonomic and ecological groups (Jones et al. 2017). Our knowledge about the responses of other peracarids is scarce. For example, the abundance of isopods before and after disturbance events was similar, but data about changes in isopod species richness are still not available (Jones et al. 2017). At the same time, the APEI3, which has been designed for conservation purposes (Wedding et al. 2013, Jones et al. 2019), had the lowest abundance and diversity of tanaidaceans, most probably resulting from low food availability, associated with biogeochemical conditions different to those in the other license areas of the CCFZ (Volz et al. 2018). Thus, its role as a potential source area in recovery processes might be questioned, although only five samples were analysed. Nevertheless, our data should be confronted with current conservation strategy programs associated with deep-sea mining (Dunn et al. 2018), but it is also obvious that further, more extensive sampling in the APEI 3 area is needed. Each license area and the APEI 3 were sampled on a small scale, leading us to infer that the sampling effort war not high enough to represent the entire area. Generally, our results are in agreement with previous suggestions that the impact of mining on benthic fauna in the CCFZ is difficult to predict and needs further comprehensive analysis; most likely, a delay in commercial exploitation is appropriate 
(Vanreusel et al. 2016, Kaiser et al. 2017, Kim 2017). It should also be mentioned that most of the tanaidacean species recorded in our study are new to science, and the planned mining activities might affect taxa that are even not properly described and of which we know nothing in terms of their role in the functioning of deep-sea ecosystems. According to Van Dover et al. (2017), such a substantial loss of biodiversity cannot be accepted without hesitation.

\section{Acknowledgements}

The material was collected and sorted within the framework of several large international projects. The project SoJaBio was financially supported by the German Research Foundation (Br 1121/37-1), both KuramBio I and II projects and the SokhoBio Project by the PTJ (German Ministry for Science and Education), grant 03G0857A, KuramBio I BMBF grant 03G0223A, as well as KuramBio II BMBF grant 03G0250A to Prof. Dr. Angelika Brandt, University of Hamburg, now Senckenberg Museum, Frankfurt, Germany.

The projects were also supported by the Russian Foundation of Basis Research (projects 13-04-02144, 16-04-01431), the Council of the President of the Russian Federation (project MK-2599.2013.4), Russian Federation Government grant No 11.G34.31.0010, grant of Presidium of the Far East Branch of RAS (12-I-P30-07), Otto Schmidt Laboratory grant (OSL-14-15). The taxonomic processing of the different taxa was supported by the Russian Science Foundation (14-50-00034); biogeography and distribution study was supported by the Russian Ministry of Science and Education (Project 14.616.21.0077, ID No. RFMEF161617X0077).

We thank the crews of the RVs Sonne and Akademik M.A. Lavrentyev for their help on board and all student helpers and technicians for support and help with sorting of the extensive expedition material.

This study was conducted in the framework of the Joint Programming Initiative Healthy and Productive Seas and Oceans (JPI Oceans) project "Ecological Aspects of Deepsea Mining" (project EcoResponse Assessing the Ecology, Connectivity and Resilience of Polymetallic Nodule Field Systems - Chief scientist: Prof. Dr. Pedro Martínez Arbizu). The tanaidacean study was funded by the Polish National Science grant UMO2016/21/B/NZ8/04702. We want to thank two anonymous reviewers for their constructive comments.

\section{Declarations of interest: none}




\section{References}

Amon DJ, Hilario A, Arbizu PM, Smith CR 2017. Observations of organic falls from the abyssal Clarion-Clipperton Zone in the tropical eastern Pacific Ocean. Marine Biodiversity 47: $311-321$.

Blazewicz-Paszkowycz M, Bamber R, Anderson G 2012. Diversity of Tanaidacea (Crustacea: Peracarida) in the world's oceans - how far have we come? PLoS ONE 7: e33068

Blazewicz-Paszkowycz M, Pabis K, Jóźwiak P 2015. Tanaidacean fauna of the KurilKamchatka Trench and adjacent abyssal plain - abundance, diversity and rare species. DeepSea Research Part II-Topical Studies in Oceanography 111: 325-332.

Bonifacio P, Menot L 2018. New genera and species from the Equatorial Pacific provide phylogenetic insights into deep-sea Polynoidae (Annelida). Zoological Journal of the Linnean Society $20: 1-81$

Brandt A, Brixa S, Brökeland W, Choudhury M, Kaiser S, Malyutina M 2007. Deep-sea isopod biodiversity, abundance, and endemism in the Atlantic sector of the Southern Ocean results from the ANDEEP I-III expeditions. Deep Sea Research Part II: Topical Studies in Oceanography 54: 1760-1775

Canning-Clode J, Valdivia N, Molis M, Thomason JC, Wahl M 2008. Estimation of regional richness in marine benthic communities: quantifying the error. Limnology and Oceanography: Methods 6: 580-590.

Costello MJ, Chaudhary C 2017. Marine biodiversity, biogeography, deep-Sea gradients, and conservation. Current Biology 27: 511-527.

Dahlgren TG, Wiklund H, Rabone M, Amon DJ, Ikebe C, Watling L, Smith CR, Glover AG 2016. Abyssal fauna of the UK-1 polymetallic nodule exploration area, Clarion-Clipperton Zone, central Pacific Ocean: Cnidaria. Biodiversity Data Journal 4: e9277 
De Smet B., Pape E., Riehl T., Bonifácio P., Colson L., Vanreusel A. 2017. The community structure of deep-sea macrofauna associated with polymetallic nodules in the eastern part of the Clarion-Clipperton Fracture Zone. Frontiers in Marine Science. 4:103

Dunn DC, van Dover CL, Etter RJ, Smith CR, Levin LA, Morato T, Colaco A, Dale AC, Gebruk AV, Gjerde KM, Halpin PN, Howell KL, Johnson D, Perez JAA, Ribeiro MC, Stuckas H, Weaver P 2018. A strategy for the conservation of biodiversity on mid-ocean ridges from deep-sea mining. Science Advances 4: eaar4313.

Glover AG, Smith CR 2003. The deep-sea floor: current status and prospects of anthropogenic change by the year 2025. Environmental Conservation 30: 219-241.

Glover AG, Wiklund H, Chen C, Dahlgren TG 2018. Managing a sustainable deep-sea 'blue economy' requires knowledge of what actually lives there. eLife. 7: e41319.

Golovan OA, Błażewicz M, Brandt A, Jażdżewska AM, Jóźwiak P, Lavrenteva AV, Malyutina MV, Petryashov VV, Riehl T, Sattarova VV 2018. Diversity and distribution of peracarid crustaceans (Malacostraca) from the abyss adjacent to the Kuril-Kamchatka Trench. Marine Biodiversity. DOI: 10.1007\%2Fs12526-018-0908-3

Hauquier F, Macheriotou L, Bezerra TN, Egho G, Martínez Arbizu P, Vanreusel A 2018. Geographic distribution of free-living marine nematodes in the Clarion-Clipperton Zone: implications for future deep-sea mining scenarios. Biogeosciences DOI: 10.5194/bg-2018-492

Hein JR, Mizell K, Koschinsky A, Conrad TA 2013. Deep-ocean mineral deposits as a source of critical metals for high- and green-technology applications: Comparison with land-based resources. Ore Geology Reviews. 51: 1-14.

Herzog S, Amon DJ, Smith CR, Janussen D 2018. Two new species of Sympagella (Porifera: Hexactinellida: Rossellidae) collected from the Clarion-Clipperton Zone, East Pacific. Zootaxa. 4466: 152-163. 
Hilario A, Metaxas A, Gaudron SM, Howell KL, Mercier A, Mestre NC, Ross RE, Thurnherr AM, Young C 2015. Estimating dispersal distance in the deep sea: challenges and applications to marine reserves. Frontiers in Marine Science. 2: 6.

Jakiel A, Palero F, Blazewicz M 2019. Deep sea landscape and Pseudotanaidae (Crustacea: Tanaidacea) diversity at the Clarion-Clipperton Fracture Zone. Scientific Reports (in press)

Janssen A, Kaiser S, Meißner K, Brenke N, Menot L, Arbizu PM 2015. A reverse taxonomic approach to assess macrofaunal distribution patterns in abyssal Pacific polymetallic nodule fields. PlosONE. 10: e0117790

Jones DO, Kaiser S, Sweetman AK, Seetman AK, Smith CR, Menot L, Vink A, Trueblod D, Greinert J, Billett DSM, Arbizu PM, Radziejewska T, Singh R, Ingole B, Stratmann T, Simon-Lledo E, Durden JM, Clark MR 2017. Biological responses to disturbance from simulated deep-sea polymetallic nodule mining. PLoS One. 12: e0171750.

Jones DOB, Durden JM, Murphy K, Gjerdec KM, Gebickac A, Colaçoe A, Moratoe T, Cuveliere D, Billett DSM 2019. Existing environmental management approaches relevant to deep-sea mining. Marine Policy. DOI: 10.1016/j.marpol.2019.01.006

Juan C, Van Rooij D, De Bruycker W 2018. An assessment of bottom current controlled sedimentation in Pacific Ocean abyssal environments. Marine Geology. 403: 20-33.

Jumars PA 1981. Limits in predicting and detecting benthic community response to manganese nodule mining. Marine Mining. 3: 213-229.

Kaiser S, Menot L, Blazewicz-Paszkowycz M, Bonifacio P, Neal L, Schnurr S, WawrzyniakWydrowsk, B 2015. Macrofauna. In: Martinez Arbizu, P., Haeckel, M. (Eds.), RV SONNE Fahrtbericht / Cruise Report SO239: EcoResponse Assessing the Ecology, Connectivity and resilience of polymetallic nodule field systems, Balboa (Panama) - Manzanillo (Mexico,) 11.03.-30.04.2015. GEOMAR Report, N. Ser. 025. GEOMAR Helmholtz-Zentrum für Ozeanforschung, Kiel, Germany, pp. 76-102. DOI 10.3289/GEOMAR_REP_NS_25_2015. 
Kaiser S, Smith CR, Arbizu PM 2017. Editorial: Biodiversity of the Clarion Clipperton Fracture Zone. Marine Biodiversity 47: 259-264.

Kersken D, Janussen D, Arbizu PM, 2018. Deep-sea glass sponges (Hexactinellida) from polymetallic nodule fields in the Clarion-Clipperton Fracture Zone (CCFZ), northeastern Pacific: Part II-Hexasterophora. Marine Biodiversity. doi.org/10.1007/s12526-018-0880-y

Kersten O, Smith CR, Vetter EW 2017. Abyssal near-bottom dispersal stages of benthic invertebrates in the Clarion-Clipperton polymetallic nodule province. Deep Sea Research Part I: Oceanographic Research Papers 127: 31-40.

Khripounoff A, Caprais JC, Crassous P, Etoubleau J 2006. Geochemical and biological recovery of the disturbed seafloor in polymetallic nodule fields of the Clipperton-Clarion Fracture Zone (CCFZ) at 5,000-m depth. Limnology and Oceanography. 51: 2033-2041.

Kim RE 2017. Should deep seabed mining be allowed? Marine Policy 82: 134-137.

Levin LA, Mengerink K, Gjerde KM, Rowden AA, Van Dover CL, Clark MR, RamirezLlodra E, Currie B, Smith CR, Sato KN, Gallo N, Sweetman AK, Lily H, Armstrong CW, Brider J 2016. Defining "serious harm" to the marine environment in the context of deepseabed mining. Marine Policy 74: 245-259.

Mewes K, Mogolllon JM, Picard A, Ruhlemann C, Kuhn T, Nothen K, Kasten S 2014. Impact of depositional and biogeochemical processes on small scale variations in nodule abundance in the Clarion-Clipperton Fracture Zone. Deep Sea Research Part I: Oceanographic Research Papers 91: 125-141.

Miljutin DM, Miljutina MA, Arbizu PA, Galéro J 2011. Deep-sea nematode assemblage has not recovered 26 years after experimental mining of polymetallic nodules (Clarion-Clipperton Fracture Zone, Tropical Eastern Pacific). Deep Sea Research Part I: Oceanographic Research Papers 58: 885-897. 
Ok Hwan Y, Lee HG, Kim D, Hee J, Kyeong W, Kim H, Yoo CM 2018. Characterization of deep-sea macrofauna in the Korean exploration claim area in the Clarion-Clipperton Fracture Zone, Northeastern Pacific Ocean. Ocean Science Journal. 53:301-314.

Pabis K, Błażewicz-Paszkowycz M, Jóźwiak P, Barnes DKA 2015. Tanaidacea of the Amundsen and Scotia Seas: an unexplored diversity. Antarctic Science. 27: 19-30.

Renaud-Mornant J, Gourbault N 1990. Evaluation of abyssal meiobenthos in the eastern central Pacific (Clarion-Clipperton fracture zone). Progress in Oceanography 24: 317-329.

Singh R, Miljutin DM, Vanreusel A, Radziejewska T, Miljutina MM, Tchesunov A, Bussau C, Galtsova V, Arbizu PM 2016. Nematode communities inhabiting the soft deep-sea sediment in polymetallic nodule fields: do they differ from those in the nodule-free abyssal areas? Marine Biology Research 12: 345-359.

Taboada S, Riesgo A, Wiklund H, Paterson GLJ, Koutsouveli V, Santodomingo N, Dale AC, Smith CR, Jones DOB, Dahlgren TG, Glover AG 2018. Implications of population connectivity studies for the design of marine protected areas in the deep sea: An example of a demosponge from the Clarion-Clipperton Zone. Molecular Ecology. 27: 4657-4679.

Van Dover CL, Ardron JA, Escobar E, Gianni M, Gjerde KM, Jaeckel A, Jones DOB, Levin LA, Niner HJ, Pendleton L, Smith CR, Thiele T, Turner PJ, Watling L, Weaver PPE 2017. Biodiversity loss from deep-sea mining. Nature Geoscience. 10: 464-465.

Vanreusel A, Hilario A, Ribeiro PA, Menot L, Arbizu PM 2016. Threatened by mining, polymetallic nodules are required to preserve abyssal epifauna. Scientific Reports. 6: 26808

Volz JB, Mogollón JM, Geibert W, Martínez Arbizu P, Koschinsky A, Kastena S 2018. Natural spatial variability of depositional conditions, biogeochemical processes and element fluxes in sediments of the eastern Clarion-Clipperton Zone, Pacific Ocean. Deep Sea Research Part I: Oceanographic Research Papers. 140: 159-172. 
Wedding LM, Friedlander AM, Kittinger JN, Watling L, Gaines SD, Bennett M, Hardy SM, Smith CR 2013. From principles to practice: a spatial approach to systematic conservation planning in the deep sea. Proceedings of the Royal Society B: Biological Sciences. 280: 1773.

Wei CN, Rowe GT, Hubbard GF, Scheltema AH, Wilson GDF, Petrescu I, Foster JM, Wicksten MK 2010. Bathymetric zonation of deep-sea macrofauna in relation to export of surface phytoplankton production. Marine Ecology Progress Series. 399: 1-14.

Wilson GDF 2017. Macrofauna abundance, species diversity and turnover at three sites in Clipperton-Clarion Fracture Zone. Marine Biodiversity. 47: 323-347.

Zeppilli D, Pusceddu A, Trincardi F, Danovaro R 2016. Seafloor heterogeneity influences the biodiversity-ecosystem functioning relationships in the deep sea. Scientific Reports. 6: 26352.

\section{Figures}

Fig. 1. Species accumulation curves.

Fig. 2. Numbers of species present in $1,2,3 \ldots$ areas.

Fig. 3 Median density (N), species richness (S) and diversity (Shannon Index) with quartiles in each of the studied areas.

Fig. 4. Dendrogram of samples for the Bray-Curtis similarity (non-transformed data, group average method). (Dotted lines indicate the stations that cannot be significantly differentiated by SIMPROF) 


\section{Highlights}

- First large scale quantitative assessment of tanaidacean communities associated with polymetallic nodule fields

- Unique species composition associated with different licence areas of the Clarion Clipperton Fracture Zone

- Very low diversity and abundance of tanaidaceans in the Area of Particular Environmental Interests (APEI3) 
Table 1. Distribution of sampling stations.

\begin{tabular}{|c|c|c|c|c|}
\hline Station number & Area & Latitude & Longitude & Depth \\
\hline 12 & $\overline{\text { BGR }}$ & $\mathrm{N}: 11^{\circ} 50.83^{\prime}$ & $\mathrm{W}: 117^{\circ} 3.56^{\prime}$ & $4117 \mathrm{~m}$ \\
\hline 15 & BGR & $\mathrm{N}: 11^{\circ} 50.66^{\prime}$ & $\mathrm{W}: 117^{\circ} 3.13^{\prime}$ & $4132 \mathrm{~m}$ \\
\hline 16 & BGR & $\mathrm{N}: 11^{\circ} 51.44^{\prime}$ & $\mathrm{W}: 117^{\circ} 3.12^{\prime}$ & $4122 \mathrm{~m}$ \\
\hline 21 & BGR & $\mathrm{N}: 11^{\circ} 51.21^{\prime}$ & $\mathrm{W}: 117^{\circ} 3.57^{\prime}$ & 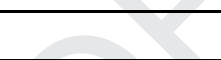 \\
\hline 23 & BGR & $\mathrm{N}: 11^{\circ} 51.00^{\prime}$ & $\mathrm{W}: 117^{\circ} 3.16^{\prime}$ & $4122 \mathrm{~m}$ \\
\hline 51 & BGR & $\mathrm{N}: 11^{\circ} 49.42^{\prime}$ & $\mathrm{W}: 117^{\circ} 31.42^{\prime}$ & $4347 \mathrm{~m}$ \\
\hline 57 & BGR & $\mathrm{N}: 11^{\circ} 48.45^{\prime}$ & $\mathrm{W}: 117^{\circ} 31.46^{\prime}$ & $4369 \mathrm{~m}$ \\
\hline 58 & BGR & $\mathrm{N}: 11^{\circ} 49.23^{\prime}$ & $\mathrm{W}: 117^{\circ} 32.50^{\prime}$ & (n) \\
\hline 60 & BGR & $\mathrm{N}: 11^{\circ} 48.46^{\prime}$ & $\mathrm{W}: 117^{\circ} 33.02^{\prime}$ & $4324 \mathrm{~m}$ \\
\hline 88 & IOM & $\mathrm{N}: 11^{\circ} 04.74^{\prime}$ & $\mathrm{W}: 119^{\circ} 39.53^{\prime}$ & $4433 \mathrm{~m}$ \\
\hline 89 & IOM & $\mathrm{N}: 11^{\circ} 04.55^{\prime}$ & $\mathrm{W}: 119^{\circ} 39.65^{\prime}$ & $4436 \mathrm{~m}$ \\
\hline 90 & IOM & $\mathrm{N}: 11^{\circ} 04.44^{\prime}$ & $\mathrm{W}: 119^{\circ} 39.85^{\prime}$ & $4434 \mathrm{~m}$ \\
\hline 94 & $\overline{\mathrm{IOM}}$ & $\mathrm{N}: 11^{\circ} 04.42^{\prime}$ & $\mathrm{W}: 119^{\circ} 39.33^{\prime}$ & $4414 \mathrm{~m}$ \\
\hline 95 & $\overline{\mathrm{IOM}}$ & $\mathrm{N}: 11^{\circ} 04.41^{\prime}$ & $\mathrm{W}: 119^{\circ} 39.35^{\prime}$ & $4418 \mathrm{~m}$ \\
\hline 97 & IOM & $\mathrm{N}: 11^{\circ} 04.37^{\prime}$ & $\mathrm{W}: 119^{\circ} 39.37^{\prime}$ & $4423 \mathrm{~m}$ \\
\hline 105 & $\overline{\mathrm{IOM}}$ & $\mathrm{N}: 11^{\circ} 04.27^{\prime}$ & $\mathrm{W}: 119^{\circ} 39.32^{\prime}$ & $4423 \mathrm{~m}$ \\
\hline 106 & IOM & $\mathrm{N}: 11^{\circ} 04.30^{\prime}$ & $\mathrm{W}: 119^{\circ} 39.29^{\prime}$ & $4425 \mathrm{~m}$ \\
\hline 107 & IOM & $\mathrm{N}: 11^{\circ} 04.33^{\prime}$ & $\mathrm{W}: 119^{\circ} 39.27^{\prime}$ & $4425 \mathrm{~m}$ \\
\hline 119 & GSR & $\mathrm{N}: 13^{\circ} 51.55^{\prime}$ & $\mathrm{W}: 123^{\circ} 15.16^{\prime}$ & $4516 \mathrm{~m}$ \\
\hline 127 & GSR & $\mathrm{N}: 13^{\circ} 50.66^{\prime}$ & $\mathrm{W}: 123^{\circ} 14.76^{\prime}$ & $4514 \mathrm{~m}$ \\
\hline 128 & GSR & $\mathrm{N}: 13^{\circ} 51.10^{\prime}$ & $\mathrm{W}: 123^{\circ} 15.12^{\prime}$ & $4511 \mathrm{~m}$ \\
\hline 137 & GSR & $\mathrm{N}: 13^{\circ} 51.36^{\prime}$ & $\mathrm{W}: 123^{\circ} 14.28^{\prime}$ & $4510 \mathrm{~m}$ \\
\hline 138 & GSR & $\mathrm{N}: 13^{\circ} 50.89^{\prime}$ & $\mathrm{W}: 123^{\circ} 14.08^{\prime}$ & $4503 \mathrm{~m}$ \\
\hline 159 & Ifremer & $\mathrm{N}: 14^{\circ} 0294^{\prime}$ & $\mathrm{W}: 130^{\circ} 0806^{\prime}$ & $4921 \mathrm{~m}$ \\
\hline 162 & Ifremer & $\mathrm{N}: 14^{\circ} 0294^{\prime}$ & $\mathrm{W}: 130^{\circ} 0756^{\prime}$ & $4951 \mathrm{~m}$ \\
\hline 169 & Ifremer & $\mathrm{N}: 14^{\circ} 0253^{\prime}$ & $\mathrm{W}: 130^{\circ} 0764^{\prime}$ & $4964 \mathrm{~m}$ \\
\hline 180 & Ifremer & $\mathrm{N}: 14^{\circ} 0250^{\prime}$ & $\mathrm{W}: 130^{\circ} 0818^{\prime}$ & $4936 \mathrm{~m}$ \\
\hline 181 & Ifremer & $\mathrm{N}: 14^{\circ} 0279^{\prime}$ & $\mathrm{W}: 130^{\circ} 0849^{\prime}$ & $4896 \mathrm{~m}$ \\
\hline 182 & Ifremer & $\mathrm{N}: 14^{\circ} 0254^{\prime}$ & $\mathrm{W}: 130^{\circ} 0765^{\prime}$ & $4957 \mathrm{~m}$ \\
\hline 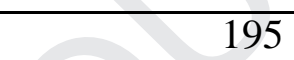 & APEI 3 & $\mathrm{~N}: 18^{\circ} 47.75^{\prime}$ & $\mathrm{W}: 128^{\circ} 21.73^{\prime}$ & $4833 \mathrm{~m}$ \\
\hline 196 & APEI 3 & $\mathrm{~N}: 18^{\circ} 47.83^{\prime}$ & $\mathrm{W}: 128^{\circ} 20.77^{\prime}$ & $4847 \mathrm{~m}$ \\
\hline 203 & APEI 3 & $\mathrm{~N}: 18^{\circ} 46.44^{\prime}$ & $\bar{W}: 128^{\circ} 21.19^{\prime}$ & $4843 \mathrm{~m}$ \\
\hline 204 & APEI 3 & $\mathrm{~N}: 18^{\circ} 46.40^{\prime}$ & $\mathrm{W}: 128^{\circ} 20.17^{\prime}$ & $4816 \mathrm{~m}$ \\
\hline 209 & APEI 3 & $\mathrm{~N}: 18^{\circ} 47.07^{\prime}$ & $\mathrm{W}: 128^{\circ} 22.35^{\prime}$ & $4819 \mathrm{~m}$ \\
\hline
\end{tabular}




\begin{tabular}{|c|c|c|c|c|c|c|c|c|}
\hline & CPE $[\mu \mathrm{g} / \mathrm{ml}]$ & \% Chl a & $\mathbf{T N}$ & TOC & TOM & clay & silt & sand \\
\hline German & $\begin{array}{l}0.229 \pm \\
0.099\end{array}$ & $\begin{array}{l}17.089 \pm \\
3.997\end{array}$ & $\begin{array}{l}0.125 \\
\pm 0.046\end{array}$ & $\begin{array}{l}0.547 \pm \\
0.186\end{array}$ & $\begin{array}{l}9.954 \pm \\
1.342\end{array}$ & $\begin{array}{l}12.225 \pm \\
1.636\end{array}$ & $\begin{array}{l}72.001 \pm \\
2.354\end{array}$ & $\begin{array}{l}15.773 \pm \\
2.543\end{array}$ \\
\hline IOM & $\begin{array}{l}0.214 \pm \\
0.065\end{array}$ & $\begin{array}{l}18.409 \pm \\
4.363\end{array}$ & $\begin{array}{l}0.140 \\
\pm 0.018\end{array}$ & $\begin{array}{l}0.600 \\
0.113\end{array}$ & $\begin{array}{l}9.801 \pm \\
0.813\end{array}$ & $\begin{array}{l}10.977 \pm \\
0.829\end{array}$ & $\begin{array}{l}72.492 \pm \\
2.039\end{array}$ & $\begin{array}{l}16.530 \pm \\
1.513\end{array}$ \\
\hline Belgian & $\begin{array}{l}0.105 \pm \\
0.049\end{array}$ & $\begin{array}{l}17.732 \pm \\
7.186\end{array}$ & $\begin{array}{l}0.163 \pm \\
0.0725\end{array}$ & $\begin{array}{l}0.473 \pm \\
0.106\end{array}$ & $\begin{array}{l}9.133 \pm \\
1.005\end{array}$ & $\begin{array}{l}16.428 \pm \\
1.401\end{array}$ & $\begin{array}{l}71.103 \pm \\
2.622\end{array}$ & $\begin{array}{l}12.467 \pm \\
2.559\end{array}$ \\
\hline French & $\begin{array}{l}0.071 \pm \\
0.026\end{array}$ & $\begin{array}{l}14.389 \pm \\
2.911\end{array}$ & $\begin{array}{l}0.122 \pm \\
0.030\end{array}$ & $\begin{array}{l}0.396 \pm \\
0.069\end{array}$ & $\begin{array}{l}9.097 \pm \\
0.865\end{array}$ & $\begin{array}{l}15.748 \pm \\
1.873\end{array}$ & $\begin{array}{l}72.833 \pm \\
1.883\end{array}$ & $\begin{array}{l}11.417 \pm \\
1.919\end{array}$ \\
\hline APEI3 & $\begin{array}{l}0.058 \pm \\
0.002\end{array}$ & $\begin{array}{l}16.537 \pm \\
7.610\end{array}$ & $\begin{array}{l}0.099 \pm \\
0.004\end{array}$ & $\begin{array}{l}0.287 \pm \\
0.014\end{array}$ & $\begin{array}{l}6.508 \pm \\
0.406\end{array}$ & $\begin{array}{l}35.475 \pm \\
5.399\end{array}$ & $\begin{array}{l}61.633 \pm \\
4.906\end{array}$ & $\begin{array}{l}2.891 \pm \\
0.808\end{array}$ \\
\hline
\end{tabular}

Table 2. Mean values if environmental variables in each of the studied areas (Hauquier et al. 2018, Volz et al. 2018). 


\begin{tabular}{|l|l|l|l|l|l|}
\hline & German & IOM & Belgian & French & APEI3 \\
\hline $\begin{array}{l}\text { Species } \\
\text { unique to } \\
\text { given area }\end{array}$ & $25(59 \%)$ & $15(48 \%)$ & $15(68 \%)$ & $19(95 \%)$ & $4(80 \%)$ \\
\hline Singletons & $16(38 \%)$ & $16(51 \%)$ & $16(72 \%)$ & $13(65 \%)$ & $5(100 \%)$ \\
\hline $\begin{array}{l}\text { Species } \\
\text { present only } \\
\text { in one } \\
\text { sample }\end{array}$ & $24(57 \%)$ & $17(54 \%)$ & $18(81 \%)$ & $16(80 \%)$ & $5(100 \%)$ \\
\hline $\begin{array}{l}\text { Total } \\
\text { number of } \\
\text { species }\end{array}$ & 42 & 31 & 22 & 20 & 5 \\
\hline
\end{tabular}

Table 3. Number and percentage of species rare and unique for each studied area. 
Table 4. Number of species common to different areas.

\begin{tabular}{|l|l|l|l|l|}
\hline & IOM & Belgian & French & APEI3 \\
\hline German & 14 & 5 & 0 & 0 \\
\hline IOM & & 3 & 0 & 1 \\
\hline Belgian & & & 1 & 0 \\
\hline French & & & & 0 \\
\hline
\end{tabular}




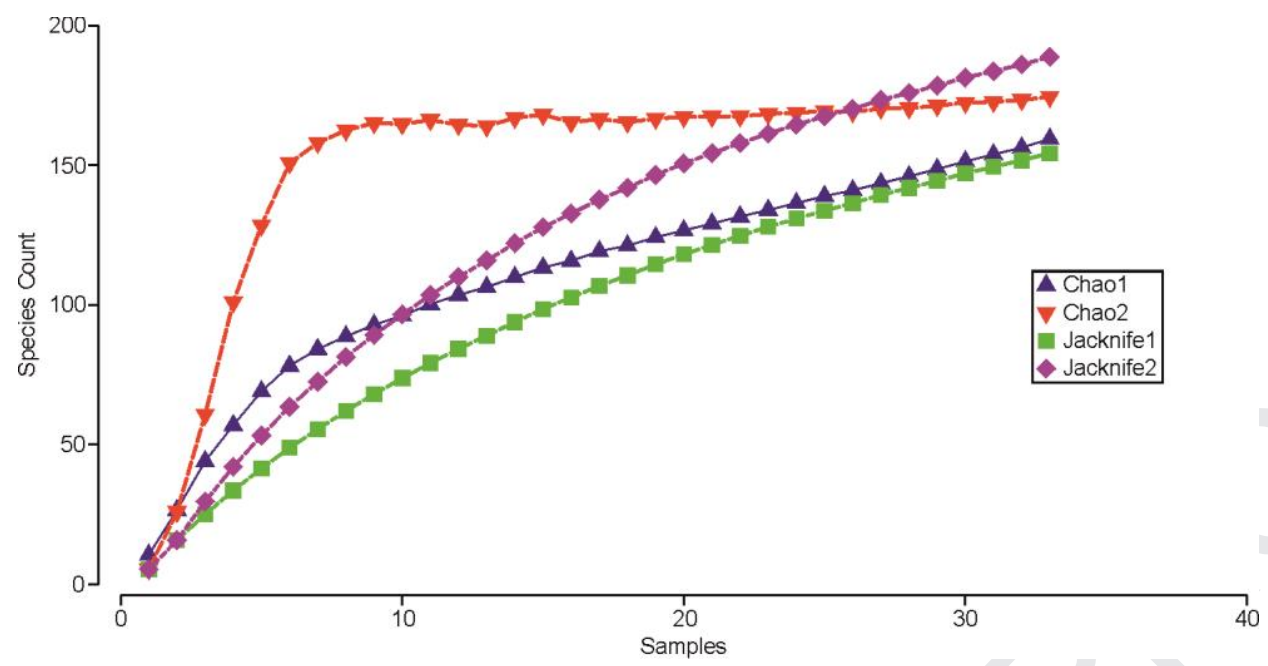




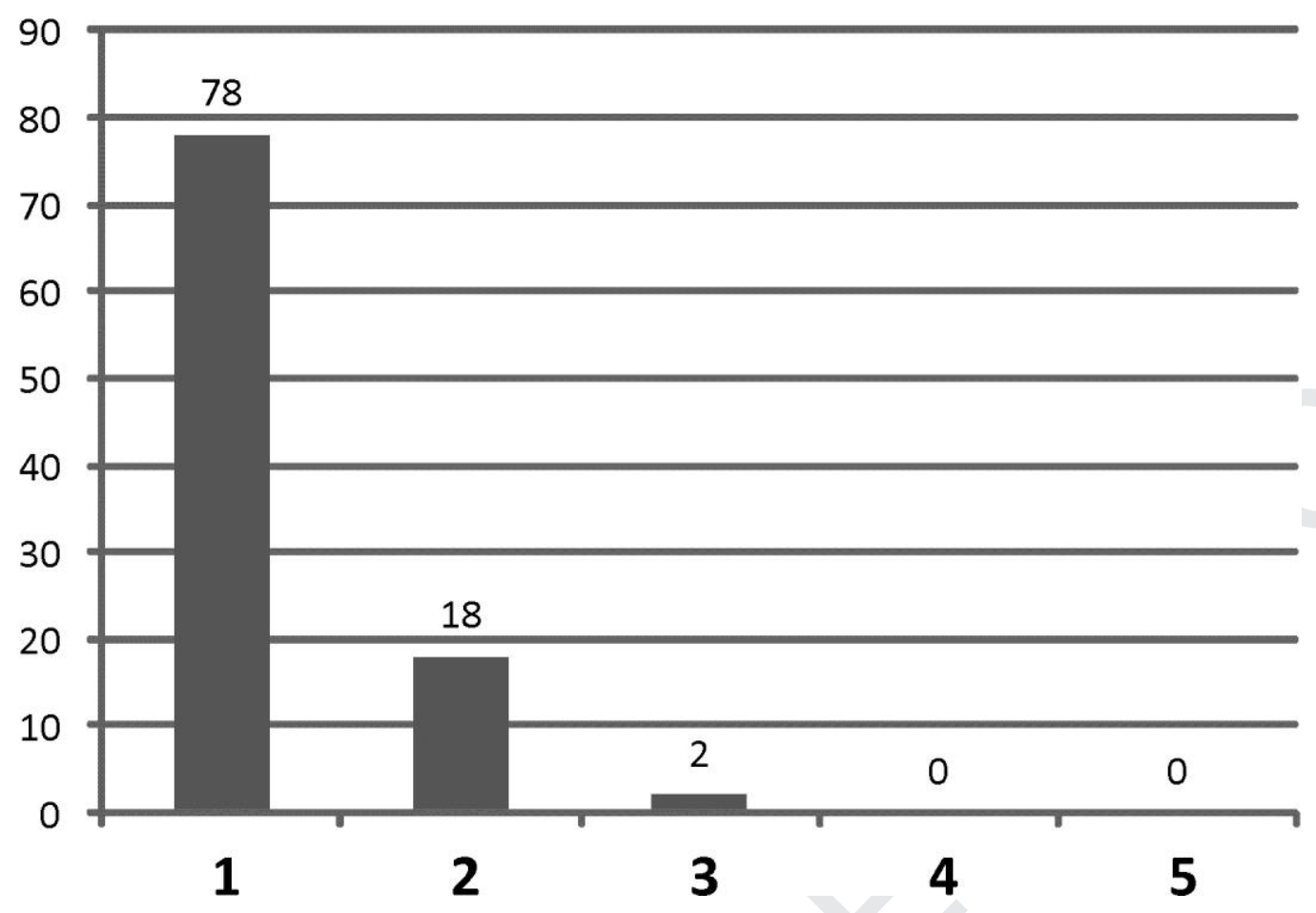




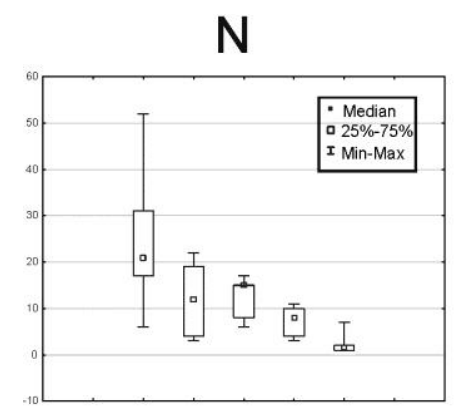

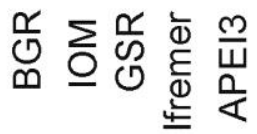

S

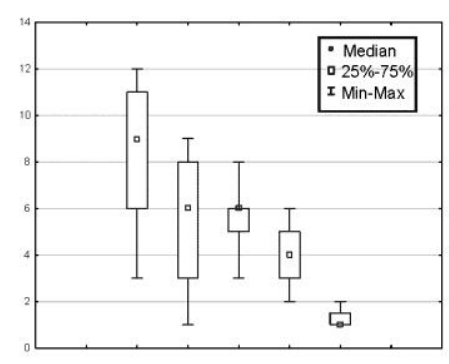

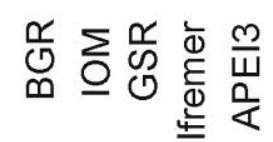

Shannon Index

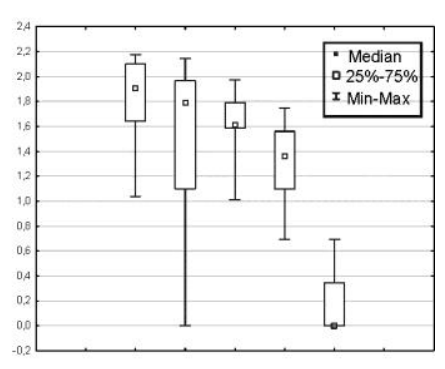

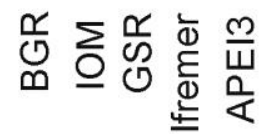




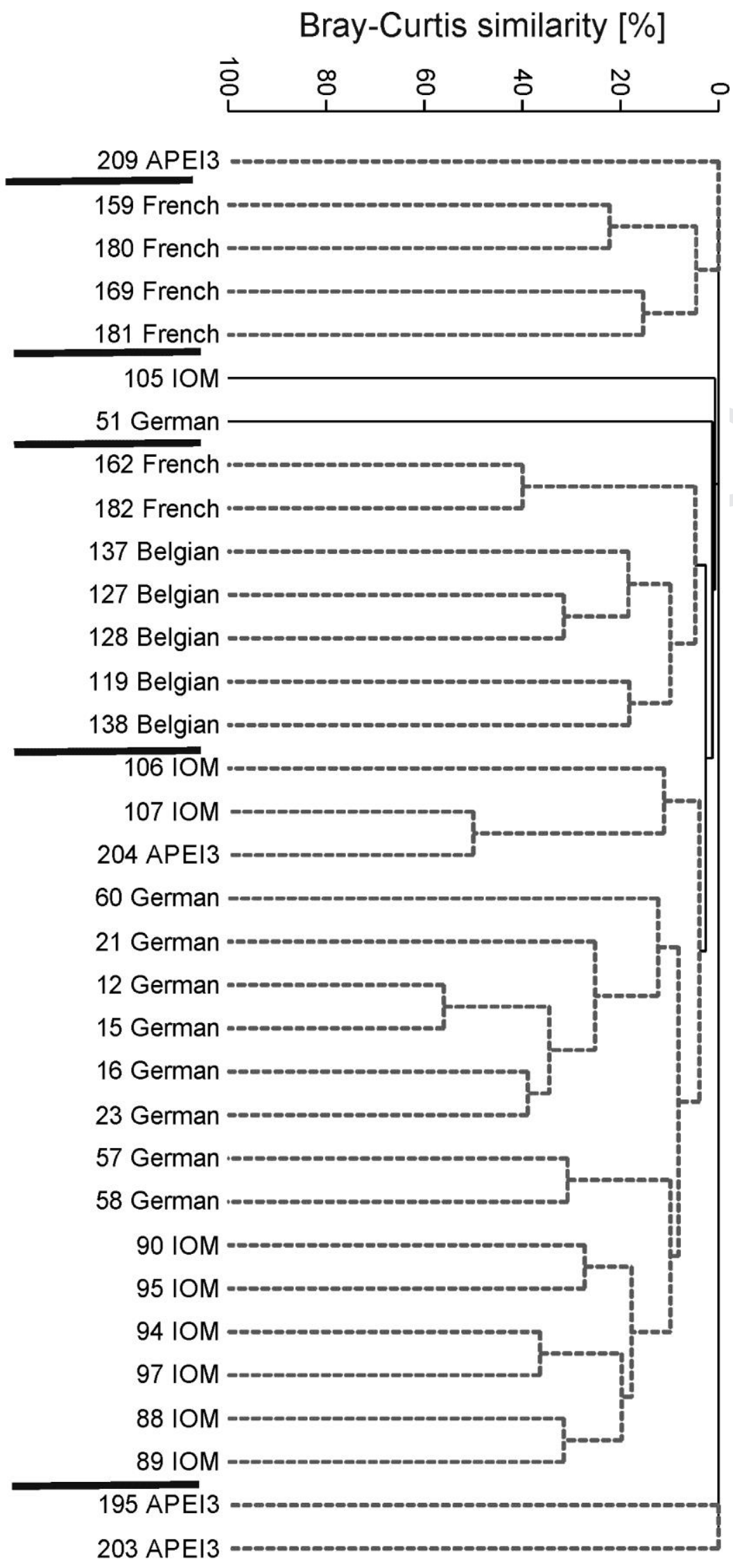

